\title{
TOURMALINE AND TOURMALINE SCHISTS FROM BELCHER HILL, COLORADO
}

BY HORACE B. PATTON

(Read before the Society August 23, 1898)

CONTENTS

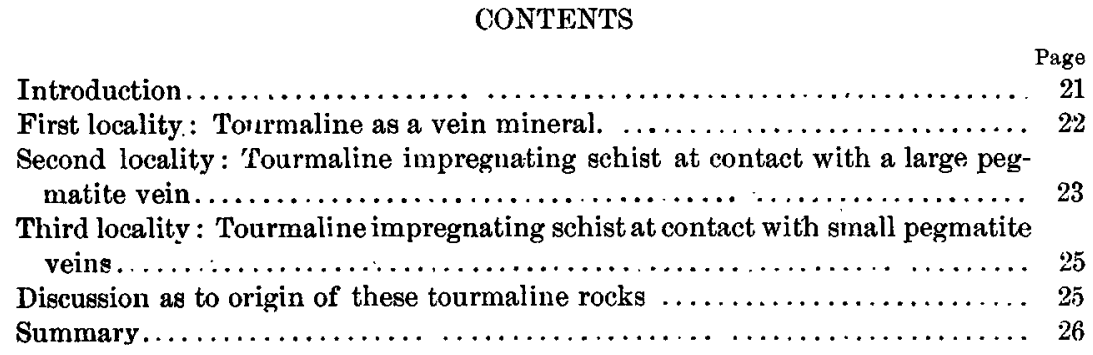

\section{INTRODUC'TION}

Tourmaline is a not uncommon mineral in the northern part of Jefferson county, Colorado. It is to be found as an ingredient of the quartzfeldspar boulders which strew the mesas bordering the foothiils west of Denver and in the beds of the streams which drain the crystalline schists of these foothills. It may also be found in place in the numerous pegmatite veins that every where cut the schists. Beautiful lustrous black crystals, often two or more inches in diameter, have been obtained from these pegmatite veins. In rare cases colors other than black may be seen, as for instance, some small crystals, about a quarter of an inch in diameter, with white centers and black margins, found in a pegmatite boulder near Golden.

While the pegmatite veins may well be considered the habitat of the Jefferson County tourmalines, in some cases this mineral occurs with somewhat different association. On the so called Belcher Hill road, one of the roads leading from Golden to Central City, are several unusually interesting occurrences of tourmaline.

This road runs north from Golden, skirting the foothills for a distance 
of some five or six miles, and then turns westward and climbs the hills in sharp zigzags until an altitude of 1,000 feet above the base is reached.

At the summit the country flattens out and the first mountain ranches begin to appear. On the way up the mountain the country rock is well exposed along the road. It consists of micaceous schists of greatly varying degrees of schistosity. Not infrequently they become extremely micaceous and are then beautifully crinkled. The schists are composed of both white and black mica associated with quartz, and sometimes, but not characteristically, with feldspar. One may see at frequent intervals during the ascent numerous veins of quartz or of quartz and feldspar containing the habitual black tourmaline. More extensive exposures, however, occur just before reaching the summit of the long climb opposite the first piece of cleared land to be seen on the right of the road. There are, in fact, three outcrops, to which attention may be specially directed, differing from each other and from most of the tourmaline occurrences of this region. They will be described separately.

\section{First locality: Tourmaline as a Vein Mineral}

An 18-inch vein of quartz and tourmaline is to be seen striking almost at right angles to the road and exposed in the roadway. The vein is not quite parallel to the cleavage direction of the mica-schists which strike east and west and dip nearly vertically. The tourmaline at this locality is a fine grained schorl-like mass more or less banded with white vein quartz. The vein may be traced for two or three hundred feet in the field to the northeast by means of fragments on the surface. Numerous blocks of this rock lie scattered along the road for 50 or 100 feet below the outcrop.

In most cases tourmaline predominates over quartz. It does not, as is usually the case, occur in coarse grains or crystals, but rather in a dense ielted mass, the fibrous character of which is evident only upon a close examination, as the fibers or needles are hardly over one millimeter in length. The banded structure of the rock is usually very marked, and the strong contrast between the white of the quartz and the black of the tourmaline is very striking. Where quartz grains are intimately mixed with tourmaline, as is not infrequently the case, this banding becomes less pronounced or entirely disappears.

A thin-section of this rock discloses under the microscope granular quartz, sometimes distinct prisms and sometimes irregular grains of tourmaline, together with a very little muscovite. In addition to these minerals may be mentioned a few small, irregular grains that show very high refractive powers and may well be considered rutile. The tourmaline is very strongly characterized under the microscope. It shows 
strong negative birefraction; also a rather high index of refraction and very striking pleochroism. In moderately thin sections the ordinary ray is almost completely absorbed and shows a dull blackish green color, while the extraordinary ray is light brown.

The effect, if any, of this vein on the adjacent schist could not be observed at the place of outcrop, but to the west of the road lie blocks of schist which show a partial impregnation by tourmaline, and also a gradual disappearing of the tourmaline in the direction of the cleavage plane. Judging from the occurrence of tourmaline at the two other localities described below, it is probable that these loose blocks came from close contact with the quartz-tourmaline vein.

\section{Second Lócality: Tourmaline impregnating Schist at Contact with a large Pegmatite Vein}

This is to be found about 500 feet up the road-that is, to the westward of the first locality. The outcrop is more extensive than at the first named locality. It consists of a pegmatite vein about 10 feet wide where it crosses the road, cutting the road diagonally with a northeastsouthwest strike. The tourmaline, which is to be found only sparingly in the vein itself, occurs impregnating the schists at contact with the vein. Just at the fence the contact may be seen well exposed. The impregnation extends about two to three feet from the line of contact, and the black streaks of tourmaline are usually parallel with the schist cleavage. To the southwest of the road the pegmatite vein takes a nearly north-and-south course, and continues about 10 feet wide for 200 or 300 feet, and then gradually widens to about double this width. On both sides of the vein the schists are thoroughly metamorphosed for a foot or two from the contact. They lose in places all traces of the original cleavage, and develop into aggregates of quartz and tourmaline to the entire exclusion of the mica. Where this alteration is most complete the streaks of tourmaline do not appear to bear any relationship to the original cleavage direction. Curiously enough, as the vein widens the tourmalinizing of the schist' becomes less and less marked, till it ceases altogether where the vein ends suddenly at its widest point.

Fragments of this tourmalinized schist are thickly strewn along both sides of the road, and the varying structures may be well studied from these fragments. In general, the rock may be said to present the appearance of a laminated or banded grayish or reddish gneiss, and without close observation one would hardly suspect the presence of tourmaline. Usually the banded schistose structure is sharply defined and the bands straight and parallel, but not infrequently a decided crinkling of the bands is to be observed similar to that noticed in the neighboring mica- 
schists. The bands vary in thickness, but are usually very thin, in some cases not over one millimeter thick.

This rock consists of quartz, tourmaline, and muscovite. Biotite, although very abundant in the immediately adjacent mica-schist, is usually entirely wanting in the tourmaline-schist. The tourmaline has evidently been formed at the expense of the biotite. The grayish or reddish portions are composed of quartz or of quartz and muscovite. Feldspar appears to be entirely lacking. In many cases the main portion of the rock is composed of a mass of quartz, with or without muscovite, through which run thin black lines of tourmaline. In still other cases the quartz-muscovite mass is penetrated in two different directions by parallel lines of tourmaline. These two series of black lines are sometimes almost at right angles to each other; at other times they make sharply oblique angles. By their intersection with each other they thus produce a beautiful reticulated structure. A still different structure is produced when one set of these lines is sharp and straight while the other is broad and wavy or crinkled.

This tourmalinized schist is cut by numerous small sharp veins of quartz or of quartz and muscovite. These vary froma lineto several inches in thickness. They sometimes are parallel, but often cross each other. These cutting veins not infrequently have affected the process of tourmalinization, inasmuch as a more intense tourmalinization is to be noticed in the immediate vicinity of the veins. Where much muscovite is present in the veins this effect appears to be less marked. Coarser crystals of tourmaline may also be seen in these narrow veins, or they may project slightly into the quartz mass of the vein.

Under the microscope the tourmaline of this locality is seen to be very similar to that of the first described locality. Usually the grains are irregular in outline, or even very ragged, and then filled with quartz inclusions. Frequently, too, there occur small darker colored pleochroic zones surrounding yellowish specks of either rutile or zircon or of some similar mineral. Occasionally the tourmaline shows well defined prismatic habit with rhombohedral terminations.

In addition to the above mentioned minerals, there also occurs a very little muscovite in the sections studied. This scarcity of muscovite, however, is only accidental, as it is very abundant in most of the hand specimens. In addition may be mentioned a few small grains of a white mineral with weak birefraction and strong index of refraction. 'They are taken to be apatite.

Photographic reproductions of these structures, as shown in figures 1 and 2, plate 1, and in figures 1 and 2, plate 2 (about one-half natural size) give but a faint idea of the delicacy of the lines and of the beauty of the original specimens, but they may serve to show the variety of the 


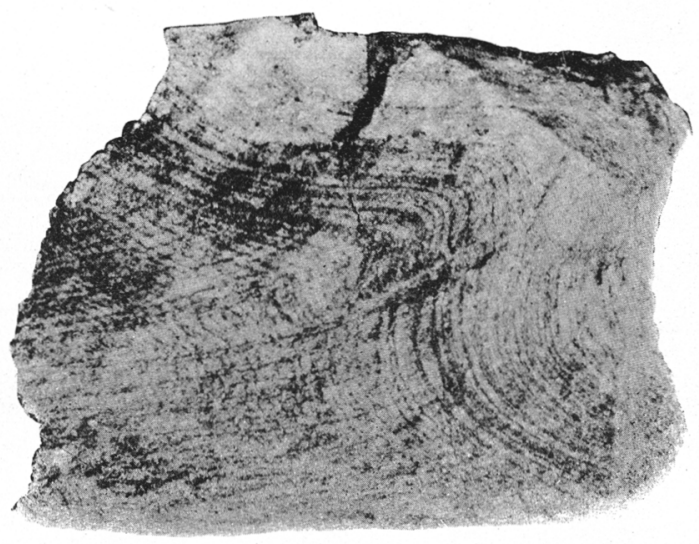

Figure 1-Tourmaline Schist

From second locality, Belcher Hill, Colorado

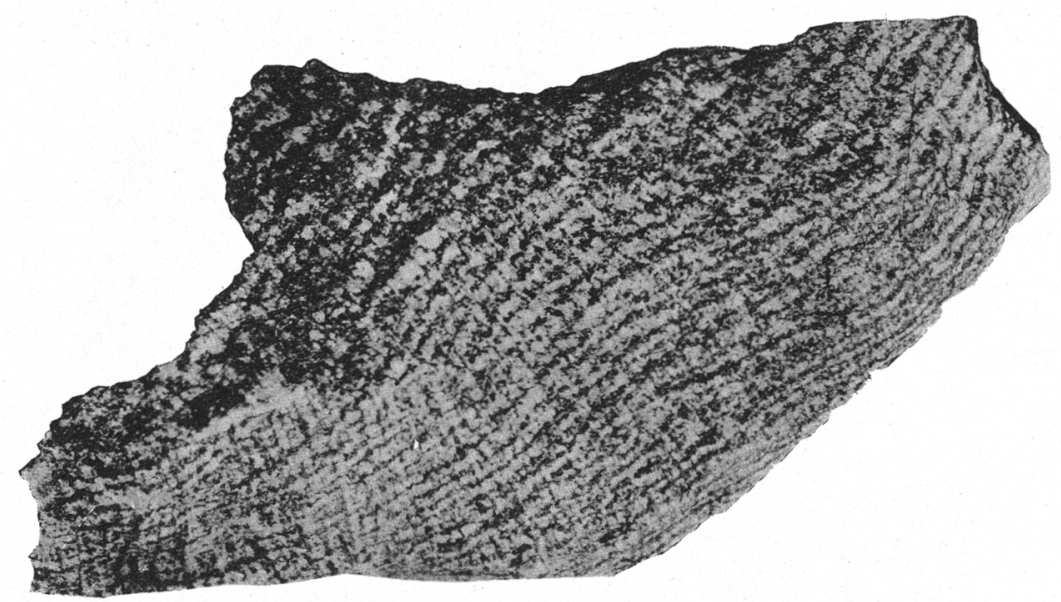

Figure 2-Tourmaline Schist

From second locality, Belcher Hill, Colorado

TOURMALINE SCHISTS 


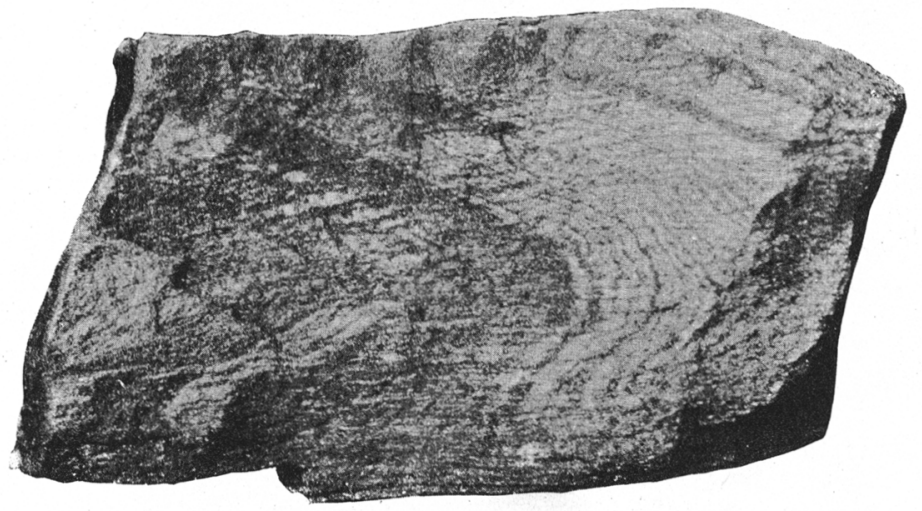

Figure 1-Tourmaline Schist

From second locality, Belcher Hill, Colorado

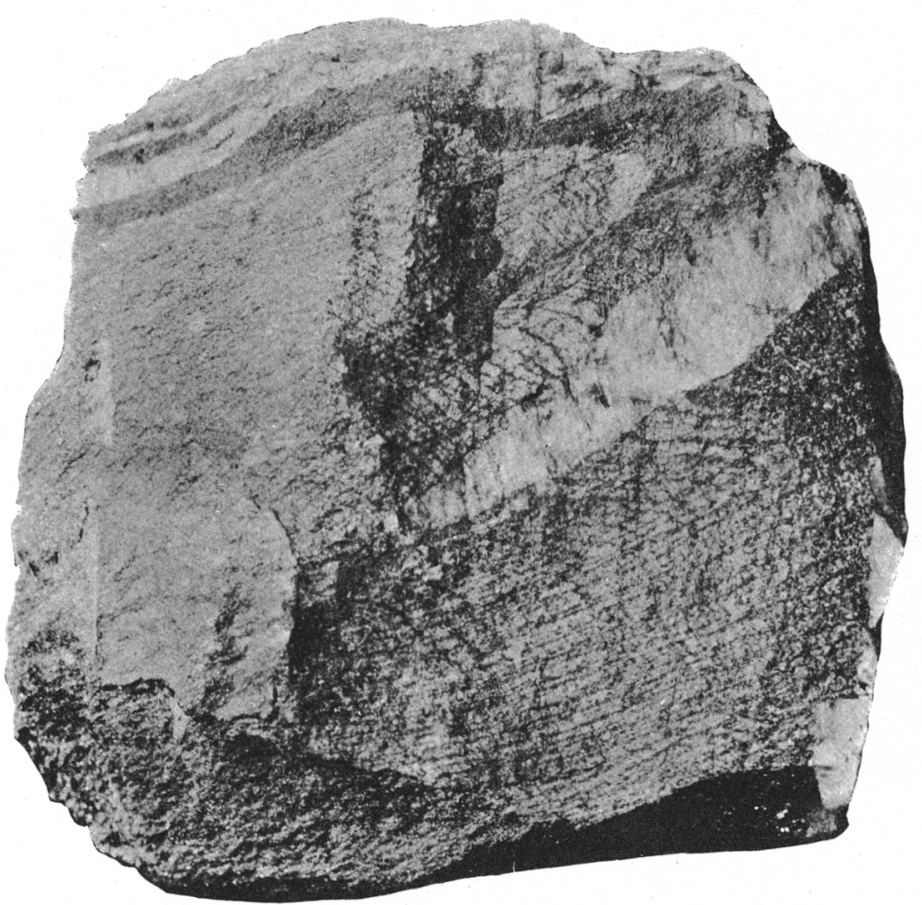

Figure 2-Tourmaline Schist

From second locality, Beleher Hill, Colorado

TOURMALINE SCHISTS 
structures involved. All the dark colored lines in these reproductions represent tourmaline, while the light colored portions are mostly quartz. In figure 1, plate 1 , and in figure 2, plate 2 may be seen the cross-hatched structure produced by narrow streaks of tourmaline crossing each other.

\section{Third Locality : Tourmaline mmpregnating Schist at Contact with small Pegmatite Veins}

Some 1,500 feet farther along the road beyond the first locality, just where one first comes in sight of the "Rocky Mountain ranch," occurs a vein of pegmatite about two to three feet in width. This vein runs straight up and down the hill at right angles to the road. It divides into branches which enclose "horses" of schist. The cleavage of the schist and the vein strike in the same direction. Here, too, the schist, which is very micaceous, is impregnated with tourmaline on both sides of the pegmatite vein, as are also the enclosed horses. The streaks of tourmaline run parallel to the vein and to the rock cleavage. The vein may be traced about 200 feet down the hill. Farther down are other veins of pegmatite, striking in the same direction and accompanied by similar alteration of the schist at contact.

At this locality the country rock has not been extremely altered at contact with the pegmatite veins, and the rock cleavage has not been apparently lessened. The schist here is a friable, soft mica-schist of a beautiful bronze-like luster. Near the contact it contains minute, delicate prisms and needles of black tourmaline scattered thickly but very irregularly throughout the mass. In places this tourmalinized rock has a well defined crinkled structure.

Under the microscope the tourmaline is seen to be in sharply defined prisms which often show double termination, one end having a very flat rhombohedron and the other end a less flat rhombohedron. Light yellow to blood red stains of iron oxide abound and explain the bronze-like luster of the rock. Quartz is not very abundant and the biotite is present only in traces.

\section{Discussion as to Origin of these Tourmaline Rocks}

As to the origin of these tourmaline rocks it is evident that at the last two localities they are local modifications of the mica-schists which form the country rock, and are limited to a narrow zone of contact with veins of pegmatite. In all three localities, and this applies to all occurrences of tourmaline seen by the author in this region, the tourmaline occurs only in or near veins. This mineral does not appear to form an important constituent of the surrounding schists. In a few cases, however, the 
country rock appeared to carry a little tourmaline, together with a large amount of biotite.

Of course, this quite agrees with what is generally known about the occurrence of tourmaline. Only a few instances are given, as far as the author is aware, where tourmaline occurs as one of the main ingredients in a schistose rock, without any connection with fissures. Such rocks, for instance, are mentioned by Zirkel as occurring in the Erzgebirge of Saxony.* Usually tourmaline is found near the margin of granite masses, or in the rocks adjacent to large masses of granite, and in either case are considered to be contact features of the granite.

A case in point, which is similar in some respects to the one under discussion, is the occurrence of tourmaline at Auerberg, in Saxony. $\dagger$ At this locality there is a vein of quartz and tourmaline cutting through a mass of mica-andalusite-hornfels near the junction with the granite. The hornfels, itself a slate rock metamorphosed by contact with granite, has been tourmalinized on both sides of the vein, the tourmaline taking the place of biotite and andalusite.

Many other cases might be quoted where tourmaline occurs in connection with fissures at or near the junction with granite. Apparently, however, there is no true granite in this region; at least there is no large mass of granite capable of producing ordinary granitic contact phenomena. The pegmatite veins of these foothills are usually composed of coarse granular aggregates of reddish microcline and quartz, with or without muscovite, and occasionally garnet. They frequently resemble segregation veins in that they shade off into the adjoining schists without any well defined vein wall. One of the veins on Belcher hill broadens out to a considerable width, but is not as large as many of the pegmatite veins of this region. It may be an intrusive dike, but in the opinion of the writer these and other pegmatite veins of the region are not of such origin. Without entering into the discussion of the origin of the pegmatite veins, the following points may be emphasized in conclusion:

\section{SUMMARY}

The tourmaline on Belcher hill occurs-

1. In separate crystals in pegmatite veins.

2. In black schorl-like masses with quartz, filling fissures in the crystalline schists.

3. In mica-schists, at the junction of veins of pegmatite or of quartz, in the form of finely disseminated grains and needles replacing biotite and sometimes feldspar and even quartz.

*Zirkel : Lehrbuch der Petrographie, vol. 3, p. 410. Leipsic, 1894.

†Zirkel : Lehrbuch der Petrographie, vol. 2, p. 119. 